\title{
Kesadaran Hukum Masyarakat Pertambangan Emas di Desa Teluk Pandak Kecamatan Tebo Tengah Kabupaten Tebo
}

Eri Sakti ${ }^{1}$, Akmal

Program Magister Pendidikan Pancasila dan Kewarganegaraan Universitas Negeri Padang, Indonesia 1erisakti07@gmail.com

\begin{abstract}
ABSTRAK
Penelitian ini bertujuan untuk melihat permasalahan yang terjadi pada aktivitas pertambangan emas, baik dalam masyarakat maupun pada pekerja pertambangan emas itu sendiri. Pelanggaran hukum yang dilakukan oleh penambang emas tidak serta merta menjadi tolak ukur baik atau tidaknya kesadaran hukum masyarakat pertambangan emas di Desa Teluk Pandak Kecamatan Tebo Tengah Kabupaten Tebo, Provinsi Jambi. Penelitian ini menggunakan penelitian kualitatif dengan metode deskriptif. Teknik pemilihan informan dilakukan dengan snowball sampling, dan menghasilkan 29 informan. Data dikumpulkan dengan metode wawancara, observasi dan dokumentasi. Selama observasi peneliti mengumpulkan beberapa data berupa foto aktivitas penambang emas, pencemaran sungai, artikel tentang penertiban penambang emas, serta data pembayaran lahan. Agar data yang diperoleh bisa dipercaya (absah), maka dalam penelitian ini dilakukan triangulasi yaitu triangulasi sumber dan waktu. Data yang diperoleh dianalisis dengan mengacu pada model analisis Miles dan Huberman dengan langkah-langkah yaitu reduksi data, model data (data display) dan penarikan kesimpulan. Hasil dari penelitian ini menunjukkan terkendalanya kesadaran masyarakat disebabkan kurangnya informasi dan pembinaan dari pemerintah tentang Undang-Undang serta implementasinya dalam penambangan.
\end{abstract}

Kata Kunci: kesadaran hukum, pertambangan emas, UU Mineral dan Batubara

\section{ABSTRACT}

The pupose of this research is to examine the problems in gold mining activities, both among the comunity and the gold mining workers. Violations of the law committed by gold miners do not necessarily serve as the benchmark for measuring the legal consciousness of the gold mining community in the Teluk Pandak village, Tebo Tengah district, Tebo Regency, Jambi province. This study was qualitative using descriptive methods. 29 informants were selected using snowball sampling. Data were collected by interview, observation and documentation. During the observation, pictures of gold mining activity, articles about gold mines, and land payment were collected. The data were then verified by triangulation of sources and times, and analyzed based on Miles and Huberman model in the sequences of: data reduction, data model (data display) and drawing conclusion. The result of this study shows the challenge in the community's legal consciousness due to the lack of information and guidance from the administration about the regulation and the implementation of the mining activity.

Keywords: legal consciousness, gold mining, Regulation on Minerals and Coal 


\section{PENDAHULUAN}

Pertambangan emas merupakan salah satu mata pencaharian masyarakat Desa Teluk Pandak Kecamatan Tebo Tengah, Kabupaten Tebo, Provinsi Jambi dengan berbagai polemik yang dihadapi diantaranya pertama dari segi hukum yaitu masalah perizinan yang berhubungan dengan UU No. 4 Tahun 2009 tentang Pertambangan Mineral dan Batubara (Minerba), yang kedua dari segi dampak lingkungan yaitu zat merkuri yang dapat berpotensi mempengaruhi kualitas kesehatan pekerja dan masyarakat (Sumantri et al., 2014).

Di tengah polemik ini, masyarakat penambang emas masih tetap bertahan. Dengan belum adanya aturan yang terperinci dan penyuluhan dari pimpinan daerah setempat, pertambangan emas tetap beroperasi mengingat keterbatasan kondisi perekonomian masyarakat, juga tingkat pendidikan masyarakat yang rendah sehingga tidak memungkinkan mencari pekerjaan yang lain.

Sementara itu, UU No 4 tahun 2009 tentang Minerba menimbulkan keresahan bagi masyarakat penambang emas mengenai aktivitas pertambangan emas; pekerjaan mereka selalu dibayang-bayangi rasa kekuatiran jika terjadi razia secara tiba-tiba oleh pihak hukum setempat. Pada 7 Februari 2018 tim aparat hukum menggelar razia penambang emas. Dalam operasi ini sedikitnya ada lima mesin dompeng yang dimusnahkan. Aktivitas penambangan juga menimbulkan keresahan pada masyarakat setempat, seperti yang disampaikan oleh Yulianti et al. (2016), dampak pertambangan emas yaitu adanya perubahan warna air yang jernih menjadi keruh kecoklatan, dan tebing-tebing menjadi runtuh.

Dalam menghadapi permasalahan di atas, perlu adanya peningkatan kesadaran hukum pada penambang emas yaitu kesadaran yang didasarkan pada konsep kesadaran diri sendiri (Rejekiningsih, 2016). Menurut Scolten dalam Ahmad, (2018) kesadaran hukum adalah kesadaran yang ada pada manusia tentang apa hukum itu atau apa seharusnya hukum itu. Ide tentang kesadaran warga-warga masyarakat sebagai dasar sahnya hukum positif tertulis ditemukan dalam ajaranajaran tentang Rechtsgefuhl atau Rechtbewustzijn yang intinya adalah bahwa tidak ada hukum yang mengikat warga-warga masyarakat kecuali atas dasar kesadaran hukumnya (Usman, 2014). Kesadaran hukum dan keyakinan hukum individu merupakan pangkal dari kesadaran hukum masyarakat (Soekanto, 1994).

Penelitian serupa pernah dilakukan oleh Nopriadi (2016), yang hasil penelitiannya lebih menitikberatkan kepada dampak aktivitas penambangan emas terhadap pencemaran air dan sosial ekonomi. Untuk meminimalisir dampak pertambangan emas perlu peningkatan kesadaran hukum masyarakat penambang emas berdasar-kan mekanisme dan aturan-aturan yang ditetapkan pemerintah (Tebo, 2013) tentang Rencana Tata Ruang Wilayah Kabupaten Tebo pasal 75 ayat (2) huruf b meliputi: a) ketentuan umum peraturan zonasi kawasan lindung, dan b) ketentuan umum peraturan zonasi kawasan budidaya.

Tulisan ini mencoba memahami tingkat kesadaran hukum masyarakat penambang emas di Desa Teluk Pandak, Provinsi Jambi, di mana mereka tetap melaksanakan aktivitas penambangan emas walaupun tidak sesuai dengan UU No. 4 tahun 2009 tentang Minerba, dan menimbulkan dampak lingkungan yang cukup signifikan. 


\section{METODE}

Penelitian ini menggunakan jenis penelitian deskriptif dengan metode kualitatif. Menurut Raco (2010) penelitian kualitatif merupakan penelitian yang cocok mendalami lingkungan, pengalaman, keadaan faktual, situasi sosial, politik, eonomi, budaya yang berlaku di suatu tempat pada suatu waktu. Teknik dan alat pengumpulan data yang dipakai dalam penelitian ini adalah wawancara, observasi dan dokumentasi. Cara pemilihan informan dilakukan dengan metode purposive sampling yang terdiri dari camat, kepala desa, tokoh masyarakat dan pelaku penambang emas. Jumlah informan ditentukan sesuai dengan kecukupan data yang dibutuhkan yaitu 29 informan. Agar data yang diperoleh bisa dipercaya (absah), maka dalam penelitian ini dilakukan triangulasi yaitu triangulasi sumber dan waktu. Triangulasi yang dilakukan yaitu, pertama triangulasi sumber berupa pertanyaan yang diajukan kepada berbagai sumber (informan) yang dapat diajak berkomunikasi langsung. Selanjutnya, triangulasi dengan cara triangulasi waktu dimana dapat dilakukan pada saat waktu senggang informan, sehingga tidak mengganggu pekerjaannya dan akan memberikan data yang lebih valid sehingga kredibel. Waktu penelitian dilakukan 2 bulan, mulai tanggal 30 September sampai dengan 30 November 2019. Karena belum ada aturan yang jelas, selama observasi peneliti tidak menemukan dokumen-dokumen masalah pertambangan emas, namun peneliti mengumpulkan beberapa data berupa foto aktivitas penambang emas, pencemaran sungai, artikel tentang penertiban penambang emas, serta data pembayaran lahan. Data yang diperoleh dianalisis dengan mengacu pada model analisis Miles dan Huberman dengan langkah-langkah yaitu reduksi data, model data (display) dan menarik kesimpulan (Emzir, 2010).

Dalam penelitian ini, kesadaran hukum masyarakat pertambangan emas dan faktor yang mendorong pelanggaran hukum oleh masyarakat pertambangan emas dibahas dengan memanfaatkan teori yang relevan.

\section{HASIL DAN PEMBAHASAN}

\section{Kesadaran Hukum Masyarakat Penambang Emas di Desa Teluk Pandak}

Kesadaran dalam diri tiap manusia timbul karena adanya dan bekerjanya akal budi dan nurani. Manusia dapat menyadari perbedaan antar dirinya dengan hal-hal lainnya, dan juga dapat melihat dan menyadari adanya perbedaan dan persamaan di antara hal yang lain, dan dengan itu mampu melakukan pengelompokan dan pemisah-misahan. Bekerjanya akal-budi, nurani dan pancaindera dalam kaitan satu dengan lainnya menyebabkan manusia memiliki kesadaran dan kemampuan memahami realita yang ada. Dengan adanya dan bekerjanya akal budi dan nurani tersebut menyebabkan terbentuknya nilai-nilai dalam kesadaran manusia, dan dengan demikian manusia memiliki nilai-nilai dan kemampuan untuk menilai, memahami dan membedakan pengertian-pengertian: baik, buruk, salah, benar, adil, tidak adil, manusiawi, tidak manusiawi, bermoral, tidak bermoral, sopan, tidak sopan, boleh, atau tidak boleh, layak, tidak layak, dan sebagainya. Semua ini terjadi dalam kesadaran manusia individual (Is, 2017). Timbulnya kesadaran diri tersebut dapat diproyeksikan pada Gambar 1. 
Gambar 1. Diagram Timbulnya Kesadaran Diri

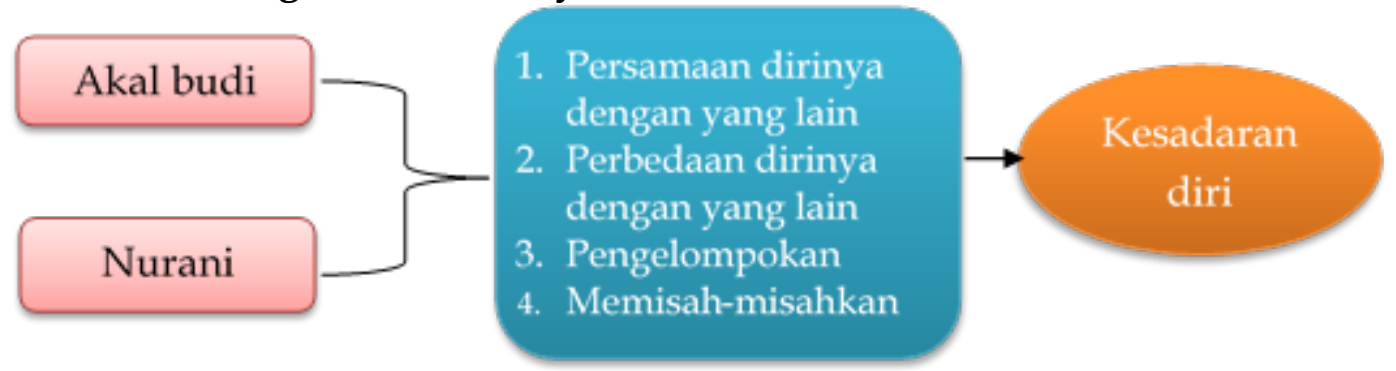

Sumber: Diolah peneliti (2020)

Pertambangan Emas di Desa Teluk Pandak Kabupaten Tebo sudah beroperasi cukup lama. Pertambangan ini tidak memiliki perizinan dari pemerintah sesuai dengan UU No 4 Tahun 2009 tentang Minerba yang menegaskan tentang kewenangan pemberian Izin Usaha Pertambangan (IUP) (Presiden Republik Indonesia, 2009), meskipun dalam UU No 4 tahun 2009 tentang Minerba mengatur tentang perizinan oleh pemerintah yang harus diketahui oleh masyarakat petambang emas, sejauh peneliti melakukan penelitian kepada pekerja tambang belum ada dari pihak pemerintah yang melakukan upaya untuk mengidentifikasi wilayah-wilayah yang diperbolehkan untuk beroperasi, serta memberikan upaya perizinan pertambangan rakyat kepada masyarakat penambang emas.

Dari hasil penelitian ditemukan bahwa masyarakat petambang emas di Desa Teluk Pandak Kecamatan Tebo Tengah mempunyai beberapa masalah bentuk kesadaran hukum, di antaranya:

\section{Pembelian Lahan atau Lokasi Pertambangan Tanpa Izin (PETI)}

Bagi masyarakat penambang emas, lahan atau lokasi untuk aktivitas pengerukan sangat diutamakan, karena untuk mendapatkan emas tersebut harus ada tempat penggalian atau pengerukan sehingga puing-puing emas tersebut dapat diambil. Lahan yang dimaksud bisa daratan atau sungai. Terbatasnya lokasi untuk mencari emas membuat masyarakat berpikir bagaimana usaha tambang tersebut tetap berjalan dengan semestinya. Sebelumnya mereka mengeruk di tengah-tengah sungai Batang Hari, tetapi semakin hari emas tersebut habis dan tidak dapat diperbaharui, sehingga mereka mulai bergeser ke wilayah-wilayah pemukiman warga seperti tebing atau lahan kosong warga.

Untuk melakukan pekerjaan di lokasi tesebut tentu mereka harus berhadapan dengan si tuan tanah. Kesepakatan di antara mereka harus terjalin sehingga tidak terjadi pelanggaran hukum karena menyerobot lahan orang lain. Oleh karena itu, masyarakat petambang emas membeli lahan tersebut untuk aktivitas pekerjaan mereka. Akan tetapi, lahan tersebut tidak mempunyai izin untuk pertambangan, hanya dimiliki sebagai lahan biasa saja. Oleh karena itu, lahan tersebut, walaupun sudah dibeli, tidak sesuai dengan UU Minerba karena tidak ada izin pertambangan.

\section{Sewa Lahan atau Lokasi Tambang}

Selain berusaha membeli lahan untuk aktivitas penambangan emas, 
penambang juga berusaha dengan cara sistem sewa. Dengan cara ini, biasanya pemilik lahan menawarkan kepada penambang emas untuk melakukan aktivitas pengerukan emas di area tersebut. Dari hasil observasi dan wawancara yang dilakukan peneliti, ditemukan bahwa masyarakat penambangan emas mempunyai kesadaran hukum yang berkaitan dengan aktivitas mereka. Bagi yang tidak mempunyai lahan sendiri, mereka tidak mau melakukan aktivitas penambangan di lokasi yang bukan hak milik mereka. Oleh karena itu apabila warga memberikan izin dengan kesepakatan yang telah ditentukan seperti dengan sistem sewa, maka pekerja tambang mulai melakukan kegiatan pengerukan di wilayah tersebut.

\section{Pembayaran Pungutan Oknum}

Pekerjaan penambangan emas bukanlah sebuah pekerjaan yang mudah, melainkan banyak mengandung resiko. Selain resiko kecelakaan dalam bekerja, melanggar hukum, terdapat resiko yang lain yaitu pemalakan yang dilakukan oleh oknum yang tidak bertanggung jawab. Hasil penelitian ini menunjukkan bahwa pekerja tambang emas sangat patuh kepada oknum-oknum yang bermain di lokasi penambangan tersebut, mereka tidak merasa keberatan untuk mengeluarkan uang kepada oknum tersebut demi keamanan pekerjaan mereka.

Dari uraian tersebut dapat disimpulkan bahwa kesadaran hukum masyarakat pertambangan emas ini masih terkendala. Di satu sisi, mereka menyadari bahwa mereka menambang secara liar, dan merasa tidak aman dalam menambang emas, sehingga mereka melakukan upaya-upaya seperti membayar pungutan ke oknum. Di sisi lain, pemerintah sendiri tidak memberikan informasi dan batasan-batasan tentang wilayah penambangan emas.

Dalam hal ini perlu adanya penertiban yang sah dan resmi dari pemerintah agar kesadaran hukum masyarakat terlakasana, senada dengan pernyataan Ahmad (2018), kesadaran hukum berarti adanya pengetahuan hukum, pemahaman hukum, sikap hukum dan perilaku hukum tentang pandangan-pandangan yang hidup dalam masyarakat tentang apa itu hukum dan apa yang seyogyanya kita lakukan.

Kepatuhan terhadap hukum pemerintah yang resmi dalam tata cara penggalian golongan $\mathrm{C}$ atau Minerba harus berlandaskan kepada konsep pendekatan dan pemberian solusi dari pemerintah, karena masyarakat tidak boleh dibenturkan oleh peraturan yang melarang karena tidak ada perizinan saja, melainkan juga didasarkan pada hak dan kewajiban sebagai warga negara sesuai dengan UU No 391999 pasal 2. Negara Republik indonesia mengakui dan menjunjung tinggi hak asasi manusia dan kebebasan dasar manusia sebagai hak yang secara kodrati melekat pada dan tidak terpisahkan dari manusia, yang harus dilindungi, dihormati, dan ditegakkan demi peningkatan martabat kemanusiaan, kesejahteraan, kebahagiaan, dan kecerdasan serta keadilan.

\section{Faktor Pendorong Pelanggaran Hukum pada Masyarakat Pertambangan Emas di Desa Teluk Pandak Kecamatan Tebo Tengah Kabupaten Tebo}

Seseorang bersikap patuh pada kaidah-kaidah hukum bukan saja karena satu alasan, akan tetapi karena dilatarbelakangi oleh berbagai alasan. Kepatuhan hukum pada hakikatnya adalah "kesetiaan" seseorang atau subyek hukum terhadap hukum 
itu, yang diwujudkan dalam bentuk perilaku yang nyata. Ada beberapa sebab mengapa orang menaati hukum, yaitu orang merasakan bahwa peraturan-peraturan itu dirasakan sebagai hukum karena ia harus menerima supaya ada rasa ketentraman, dan karena masyarakat menghendakinya dan karena adanya paksaan (sanksi) sosial (Utrecht: (Rosana, 2014).

Dari pendapat di atas, alasan mengapa seseorang itu patuh atau taat pada hukum, di mana setiap individu itu berbeda-beda di dalam memberikan alasannya, maka dengan demikian akan timbul di dalam lingkungan masyarakat berbagai derajat kepatuhan terhadap hukum seperti yang dikemukakan oleh G. P. Hoefnagles (Poerbacaraka, 1986) dalam (Fadillah, 2016) antara lain:

1. Seseorang bersikap tindak atau berperikelakuan sebagaimana diharapkan oleh hukum dan menyetujuinya sesuai dengan sistem nilai-nilai dari mereka yang berwenang.

2. Seseorang berperikelakuan sebagaimana diharapkan oleh hukum dan menyetujuinya, akan tetapi dia tidak setuju dengan penilaian yang diberikan oleh yang berwenang terhadap hukum yang bersangkutan.

3. Seseorang mematuhi hukum, akan tetapi dia tidak setuju dengan kaidah-kaidah tersebut maupun pada nilai-nilai dari yang berwenang.

4. Seseorang tidak patuh pada hukum, akan tetapi dia menyetujuinya dan demikian juga terhadap nilai-nilai dari mereka yang berwenang.

5. Seseorang sama sekali tidak menyetujui kesemuanya dan dia pun tidak patuh pada hukum (melakukan protes).

Dengan demikian dapat ditarik kesimpulan bahwa dalam kehidupan masyarakat itu terdapat bermacam-macam derajat kepatuhan terhadap hukum, mulai dari tingkat derajat konformitas yang tinggi sampai pada mereka yang dinamakan golongan non-konformitas yang memiliki derajat kepatuhan yang rendah terhadap hukum. Oleh sebab itu tinggi rendahnya derajat kepatuhan terhadap hukum ini berkaitan dengan taraf kesadaran hukum yang didasarkan pada pengetahuan tentang peraturan, pengetahuan tentang isi peraturan, sikap terhadap peraturan dan perikelakuan yang sesuai dengan peraturan.

Faktor pendorong pelanggaran hukum pada masyarakat pertambangan emas di Desa Teluk Pandak Kecamatan Tebo Tengah Kabupaten Tebo di antaranya:

\section{Pola Pikir}

Bagi masyarakat di sebagian desa di Kabupaten Tebo menganggap bahwa kekayaan alam yang ada disekitarnya adalah milik mereka dan mereka merasa bebas untuk melakukan apa saja, karena bagi mereka kehidupan mereka lebih penting, dan soal akibat atau dampak dari pekerjaan itu adalah urusan belakangan, karena menyambung hidup adalah kebutuhan pokok yag tidak bisa ditawar.

\section{Ekonomi}

Kebutuhan ekonomi adalah sesuatu yang harus dipenuhi oleh manusia. Manusia akan melakukan hal apapun untuk mendapatkan sesuatu hal yang dibutuhkan untuk memenuhi kebutuhan ekonomi. Faktor ekonomi mencakup seluruh intensitas kebutuhan seperti kebutuhan primer dan sekunder, jadi 
masyarakat akan terdorong melakukan pekerjaan yang dia mampu agar menambah pendapatan yang lebih.

Berdasarkan hasil observasi dan wawancara di lapangan, peneliti menemukan munculnya penambangan emas di Desa Teluk Pandak Kecamatan Tebo Tengah disebabkan faktor ekonomi yang rendah, karena tingkat ekonomi yang rendah mengakibatkan seseorang melakukan pekerjaan sebagai penambang emas.

\section{Pendidikan}

Dalam dunia kerja pendidkan dan kemampuan sangat diperlukan dan kedua-keduanya sama-sama penting. Pendidikan adalah salah satu aspek penting dalam kehidupan manusia, banyak yang meyakini kesuksesan dan karir seseorang ditentukan oleh pendidikan. Pendidikan juga menjadi tolak ukur bagi perusahaan dan kantor-kantor dalam merekrut karyawannya.

Menurut Muhson, Wahyuni, \& Mulyani, (2012) pendidikan merupakan salah satu sasaran pokok pemerintah dalam rangka meningkatkan kesejahteraan rakyat. Pada kehidupan sekarang ini semua orang berkepentingan terhadap jalannya pendidikan karena pendidikan merupakan wadah pembinaan tenaga kerja, dapat menambah lapangan pekerjaan, serta untuk memperoleh status dalam masyarakat.

\section{Tabel 1. Karakteristik Pekerja Pertambangan Emas}

\begin{tabular}{lll}
\hline Karakteristik & kategori & Jumlah \\
\hline Pendidikan & Tamat SD & 23 orang \\
& Tamat SMP & 2 orang \\
& Tamat SMA & - \\
\hline Jumlah & & 25 orang \\
\hline
\end{tabular}

Berdasarkan Tabel 1, karakteristik pekerja pertambangan emas di Desa Teluk Pandak Kecamatan Tebo Tengah Kabupaten Tebo tahun 2019, dari 25 informan hanya terdapat 2 orang yang lulusan SMP dan 23 orang yang tamatan SMP. Artinya 92\% pekerja penambang emas hanya lulusan Sekolah Dasar. Faktor inilah yang menyebabkan sulitnya penambang emas mencari pekerjaan lain sehingga mereka menekuni pekerjaan menambang emas meskpun menghadapi berbagai rintangan dan polemik.

\section{Harga Emas yang Tinggi}

Pada saat ini harga emas di Kabupaten Tebo cukup tinggi yaitu mencapai Rp540.000/gram sehingga mendorong masyarakat melakukan penambangan emas. Harga ini dianggap sebagai solusi untuk pemenuhan kebutuhan kehidupan yang menjanjikan, mengingat kondisi ekonomi pasar yang melambung tinggi, sehingga mengalahkan ketertarikan untuk berusaha di bidang pertanian.

Berdasarkan hasil observasi dan wawancara yang peneliti lakukan di lapangan, ditemukan bahwa sebagian masyakat yang sebelumnya adalah petani karet, yang menyadap karet untuk kebutuhan perekonomian keluarga, sekarang bekerja sebagai penambang emas. Petani karet lebih tergiur dengan hasil penjualan emas dibandingkan dengan hasil penjualan karet yang pernah mereka dapatkan. 


\section{Terbatasnya Lapangan Pekerjaan}

Kondisi tingkat pendidikan masyarakat di daerah aliran Sungai Batang Hari di Desa Teluk Pandak Kecamatan Tebo Tengah masih di bawah rata-rata, yaitu hanya tamatan SD. Hal ini menyebabkan sangat sulit bagi mereka untuk memperoleh pekerjaan.

Berdasarkan hasil observasi dan wawancara yang peneliti lakukan di lapangan, ditemukan bahwa selain faktor tingkat pendidikan yang rendah, terbatasnya lapangan pekerjaan Desa Teluk Pandak Kecamatan Tebo Tengah pun menyebabkan mereka melakukan pekerjaan sebagai penambang emas yang lebih instan dalam mencari uang untuk kebutuhan keseharian, dan pekerjaan sebagai penambang emas pun menjadi suatu pekerjaan yang tidak mempunyai pesyaratan yang sulit, hanya bermodalkan tenaga.

\section{Adanya Sokongan dari Oknum Penegak Hukum}

Ada pihak-pihak tertentu atau sekelompok orang yang melindungi kegiatan Penambangan Emas Tanpa Izin. Menurut Putra (2016), kegiatan pertambangan memiliki aktor-aktor yang berada di belakang layar, sehingga sulit tersentuh dan aktor-aktor tersebut memiliki jaringan yang kuat baik informasi maupun modal dan mampu mempengaruhi masyarakat, pemerintahan, dan petugas penegak hukum. Para aktor/oknum tersebut kadang ikut andil dan memiliki kepentingan lain yang tidak sesuai aturan dalam penertiban pertambangan emas.

\section{Rendahnya Harga Komoditi Karet}

Kecamatan Tebo Tengah adalah wilayah daratan yang kondisinya sangat mendukung untuk area perkebunan. Mayoritas masyarakat kecamatan Tebo Tengah menfaatkan lahannya untuk wilayah perkebunan karet dan sawit, dalam keseharian masyarakat petani karet menyadap karet untuk pemenuhan kebutuhan hidupnya. Hasil dari penyadapan tersebut mereka jual kepada tengkulak yang ada di Desa masing-masing.

Harga karet yang rendah dari tahun ke tahun membuat para petani karet kurang bergairah bahkan tidak sejahtera, karena pemasukan keuangan mereka tidak seimbang dengan pengeluaran. Karena pengaruh harga komoditi yang rendah, para petani karet mengalihkan pekerjaan ke pertambangan emas. Penambangan emas lebih menjanjikan hasilnya dibandingkan dengan nilai penjualan karet yang mengalami penurunan.

\section{Lemahnya Hukum}

Lemahnya penegakan hukum di wilayah di Kecamatan Tebo Tengah Kabupaten Tebo adalah menjadi salah satu faktor terjadinya pertambangan emas dengan beberapa alasan di antaranya:

a. Pemberantasan dan penghentian penambangan emas mengalami kesulitan karena pertambangan ini sudah cukup lama beroperasi.

b. Kesulitan ekonomi mejadi alasan kemanusiaan bagi pemerintah setempat, karena pihak pemerintah tidak bisa memberikan solusi pekerjaan bagi pekerja penambang emas. 
Dengan demikian perlu adanya pembinaan dan penyuluhan secara berkelanjutan dalam meningkatkan kesadaran hukum masyarakat pertambangan emas di Desa Teluk Pandak Kecamatan Tebo Tengah Kabupaten Tebo. Adanya upaya pembelian dan penyewaan lahan, serta pembayaran pungutan oknum menggambarkan bahwa pekerja pertambangan emas memiliki kesadaran terhadap aturan yang berlaku pada saat ini, tetapi pekerjaan ini tetap dilakukan karena kecil kemungkinannya masyarakat mempunyai pilihan lain, yang dipengaruhi oleh faktor ekonomi, pendidikan, dan terbatasnya lapangan pekerjaan.

\section{SIMPULAN}

Berdasarkan uraian pembahasan di atas dapat ditarik kesimpulan bahwa kesadaran hukum masyarakat masih terkendala sebab belum maksimalnya pembinaan dari pemerintah, kurangnya informasi, dan kurangnya alternatif pekerjaan. Kendala kesadaran hukum ini harus diatasi dengan perhatian secara khusus dari pemerintah setempat, karena menyangkut kehidupan masyarakat banyak. Oleh karena itu perlu adanya pembuatan peraturan desa tentang pertambangan emas, sosialisasi dan pembinaan dari pemerintah terhadap aktivitas pertambangan emas agar sesuai dengan peraturan perundang-undangan yang berlaku, penyuluhan kesadaran lingkungan, penyediaan lapangan kerja, dan penstabilan harga komoditi karet sebagai salah satu pusat perekonomian masyarakat. Pembentukan masyarakat sadar hukum dan ketaatan hukum pertambangan emas di Desa Teluk Pandak Kecamatan Tebo Tengah Kabuapaten Tebo harus dijaga dan dipelihara dengan baik karena merupakan penanaman sikap dan perilaku yang mencerminkan tanggung jawab dan jiwa bela negara. Kesadaran hukum masyarakat pertambangan emas perlu ditingkatkan dengan cara pendekatan yang aktif oleh seluruh elemen pemerintah, elemen non pemerintah dan partisispasi masyarakat. Penelitian selanjutnya disarankan untuk fokus pada kesadaran hukum masyarakat pertambangan emas dan melibatkan populasi yang lebih besar dengan sampel yang mewakili setiap daerah di Indonesia agar hasil dapat tergeneralisasikan dengan baik.

\section{REFERENSI}

Ahmad, I. (2018). Rencana Dan Strategi Peningkatan Kesadaran Hukum Masyarakat. Gorontalo Law Review, 1(1), 15-24.

Emzir. (2010). Metodologi Kualitatif analisis data. Jakarta. Raja Grafindo Persada.

Fadillah, F. (2016). KESADARAN HUKUM DALAM PELAKSANAAN KEPUTUSAN REKTOR No. 146/H35/KP/2004 TENTANG KODE ETIK MAHASISWA (Studi Kepada Mahasiswa di Universitas Negeri Padang) SKRIPSI, (146).

Indonesia, R. (1999). Undang-undang No 39 tahun 1999.

Is, M. S. (2017). Pengantar Ilmu Hukum. Kharisma Putra Utama.

Muhson, A., Wahyuni, D., \& Mulyani, E. (2012). Analisis Relevansi Lulusan Perguruan Tinggi Dengan Dunia Kerja. Jurnal Economia, 8(1), 1-11.

Nopriadi. (2016). Dampak Aktivitas Penambangan Emas Tanpa Izin (PETI) Terhadap Pencemaran Air Sungai, Sosial Ekonomi, dan Solusinya di 
Kabupaten Kuantan Singingi. Prosiding Seminar Nasional, 119-144.

Presiden Republik Indonesia. (2009). Undang-undang No 4 Tahun 2009 Tentang Pertambangan Mineral dan Batubara.

Putra, M. (2016). Kebijakan Pemerintah Kabupaten Kuantan Singingi dalam Pengendalian Kerusakan Lingkungan Hidup Akibat Pertambangan Emas Tanpa Izin ( PETI ). Jurnal JOM FISIP, 3(2), 1-15.

Raco, R. J. (2010). Metode penelitian Kualitatif, jenis, Karakteristik, dan Keunggulannya. Jakarta: Gramedia.

Rejekiningsih, T. (2016). Citizenship Education Model For The Establishment Of Legal Awareness To Implement The Social Functions Of Land Rights. Prosiding ICTTE FKIP UNS ISSN 2502-4124, 1(1), 939-945.

Rosana, E. (2014). Kepatuhan Hukum Sebagai Wujud Kesadaran Hukum Masyarakat. TAPIs, 10(1), 2-25.

Soekanto, S. (1994). Pokok-pokok Sosiologi Hukum. Jakarta. Raja Grafindo Persada.

Sumantri, A., Laelasari, E., Junita, N. R., Studi, P., Masyarakat, K., Kedokteran, F., ... Negeri, I. (2014). Logam Merkuri pada Pekerja Penambangan Emas Tanpa Izin Mercury in the Illegal Gold Mining Workers. Kesehatan Masyarakat Nasional, 8(8).

Tebo, B. (2013). Peraturan Daerah Kabupaten Tebo No 06 Tahun 2013.

Usman, A. H. (2014). Kesadaran Hukum Dan Masyarakat Pemerintah Sebagai Faktor Tegaknya Negara Hukum Di Indonesia. Wawasan Hukum, 30(1), 26-53.

Yulianti, R., Sukiyah, E., Sulaksana, N., Limun, K., Sarolangun, K., \& Limun, S. (2016). Dampak Limbah Penambangan Emas Tanpa Izin ( Peti ) Terhadap Kualitas Air Sungai Limun Kabupaten Sarolangun Propinsi Jambi. Bulletin of Scientific Contribution, 14(3), 251-262. 